\title{
Politiikkamuutosten ennakointi Delfoi-asiantuntijamenetelmällä
}

\author{
Matti Perälä ${ }^{1)}$, Olli Wuori ${ }^{1)}$, Pasi Rikkonen ${ }^{1)}$, Jyrki Aakkula ${ }^{1)}$ ja Ira Ahokas ${ }^{2)}$ \\ ${ }^{1)}$ MTT taloustutkimus, Luutnantintie 13,00410 HELSINKI, etunimi.sukunimi@mtt.fi \\ 2)Tulevaisuuden tutkimuskeskus, Rehtorinpellontie 3, 20500 TURKU, etunimi.sukunimi@tse.fi
}

\section{Tiivistelmä}

Kotimaisen elintarvikeketjun tulevaisuuteen vaikuttavat lähitulevaisuudessa mm. EU-politiikan muutospaineet, rakennekehityksen jatkuminen, alkutuotannon ja yrittäjyyden muutokset, elintarvikemarkkinoilla tapahtuvat äkilliset hintamuutokset sekä energia- ja ympäristökysymykset. Suomen maataloutta ovat viime aikoina keskusteluttaneet mm. maitokiintiöistä luopumiseen, alkutuotannon kannattavuuteen sekä kaupan vapauttamiseen liittyvät kysymykset.

Tässä tutkimuksessa sovellettiin tulevaisuudentutkimuksessa paljon käytettyä Delfoimenetelmää, joka on kyselyihin, haastatteluihin ja ryhmäkeskusteluihin perustuva asiantuntijanäkemysten keruu- ja jäsentämistekniikka. Tutkimuksessa kartoitettiin elintarvikeketjun asiantuntijoiden näkemyksiä siitä, miltä kotimainen maa- ja elintarviketalous näyttää tulevaisuudessa, mitkä ovat sen kehityksen kannalta keskeisimmät muutokset, muutostekijät ja trendit, ja mitä politiikkahaasteita toimintaympäristön muutos tuo mukanaan edettäessä kohti vuotta 2030. Delfoi-tutkimus toteutettiin joulukuun 2008 ja huhtikuun 2009 välisenä aikana haastatteluina ja kyselyillä. Kyselyssä muutostekijöitä tarkasteltiin neljässä teemassa: 1) politiikka ja instituutiot, 2) alkutuotanto ja yrittäjätoiminta, 3) elintarvikkeet ja markkinat sekä 4) energia ja ympäristö. Kyselyissä asiantuntijoilta pyydettiin arvioita muutostekijöiden tärkeydestä, toivotusta ja todennäköisestä muutoksesta sekä todennäköisen muutoksen varmuudesta. Ensimmäisellä kierroksella kysely lähetettiin 248 asiantuntijalle, ja lisäksi 26 haastateltiin (vastaus-\% 40,1). Toisella kierroksella täsmennettiin ensimmäisen kierroksen tulevaisuudenkuvia. Kysely lähetettiin 105 ensimmäisellä kierroksella vastanneelle asiantuntijalle ja lisäksi 5 heistä haastateltiin (vastaus-\% 55,5).

Politiikkahaasteiden tulkitsemiseksi kysytyt muutostekijät, muutokset ja trendit luokiteltiin strategisten haasteiden nelikenttään. Tutkimuksen kannalta keskeisimpiä muutostekijöitä ovat ne, joilla on suuri merkitys tulevaisuuden kehitykseen, ja joilla politiikkaristiriitojen todennäköisyys on suuri. Kokonaisaineistossa tärkeimmäksi muutosvoimaksi arvioitiin makean veden varannot maailmassa. Energia ja ympäristökysymyksissä tulevaisuuden politiikkahaasteina asiantuntijat pitivät koko maailmaa koskettavia ilmasto- ja ympäristömuutoksia sekä energian kokonaiskulutusta maataloudessa. Asiantuntijat arvioivat toisella, tarkentavalla kierroksella tärkeimmiksi muutosvoimiksi maatilojen kannattavuuden kehityksen Suomessa, EU:n vaikutuksen Suomen kansalliseen maatalous- ja maaseutupolitiikkaan, kotimaisten elintarvikkeiden osuuden kokonaiskulutuksesta Suomessa, EU:n maatalousbudjetin rahoituskaudella 2014 - 2020 sekä maatalouden vesistöihin tuottaman fosforikuormituksen Suomessa. Kyselyn tulokset osoittivat, että maatalouden rakennekehitys jatkuu yksikkökokojen yhä kasvaessa ja tilojen vähetessä. Rakennekehitys ei kuitenkaan yksistään ratkaise maatalouden kannattavuuteen liittyviä ongelmia vaan voi jopa osaltaan lisätä haasteita niin yrittäjän liikkeenjohdollisen osaamisen kuin työssä jaksamisen suhteen. Asiantuntijat arvioivat, että tulevaisuuden näkymiin vaikuttavat merkittävästi niin kansalliset kuin kansainväliset maatalous- ja kauppapoliittiset päätökset. Kannattavuutta ja taloutta käsittelevien muutostekijöiden osalta ruoka- ja talouskriisit korostuivat asiantuntijoiden perusteluissa.

Asiasanat: Delfoi-menetelmä, maatalouspolitiikka, maa- ja elintarviketalous, politiikkahaasteet, tulevaisuudentutkimus 


\section{Johdanto}

Kotimaisen elintarvikeketjun tulevaisuuteen vaikuttavat lähitulevaisuudessa mm. EU-politiikan muutospaineet, rakennekehityksen jatkuminen, alkutuotannon ja yrittäjyyden muutokset, elintarvikemarkkinoilla tapahtuvat äkilliset hintamuutokset sekä energia- ja ympäristökysymykset. Suomen maataloutta ovat viime aikoina keskusteluttaneet mm. maitokiintiöistä luopumiseen, alkutuotannon kannattavuuteen sekä kaupan vapauttamiseen liittyvät kysymykset. Nyt tehtävät päätökset vaikuttavat pitkälle tulevaisuuteen, siten tulevaisuuden ennakointi erilaisten vaihtoehtoisten skenaarioiden ja niiden toteutumisen vaikutustarkastelujen kautta antaa mahdollisuuden valmistautua paremmin näihin muutoksiin.

\section{Aineisto ja menetelmät}

Tutkimuksessa käytetty Delfoi-menetelmä on kyselyihin, haastatteluihin ja ryhmäkeskusteluihin perustuva asiantuntijanäkemysten keruu- ja jäsentämistekniikka. Tässä tutkimuksessa sovellettiin kaksikierroksista Delfoita, jotka toteutettiin joulukuun 2008 ja huhtikuun 2009 välisenä aikana haastatteluina ja kyselyillä. Tutkimuksessa kartoitettiin asiantuntijajoukon näkemyksiä siitä, miltä kotimainen maa- ja elintarviketalous näyttää tulevaisuudessa, mitkä ovat sen kehittymisen kannalta keskeisimmät muutokset, muutostekijät ja trendit, ja mitä politiikkahaasteita toimintaympäristön muutos tuo mukanaan edettäessä kohti vuotta 2030. Kyselyssä muutostekijöitä tarkasteltiin neljässä teemassa: 1) politiikka ja instituutiot, 2) alkutuotanto ja yrittäjätoiminta, 3) elintarvikkeet ja markkinat sekä 4) energia ja ympäristö. Kyselyssä asiantuntijoilta pyydettiin arvioita muutostekijöiden tärkeydestä, toivotusta ja todennäköisestä muutoksesta sekä todennäköisen muutoksen varmuudesta. Ensimmäisellä kierroksella kysely lähetettiin 248 asiantuntijalle, ja lisäksi 26 haastateltiin (vastaus-\% 40,1). Toisella kierroksella täsmennettiin ensimmäisen kierroksen tulevaisuudenkuvia. Kysely lähetettiin 105 asiantuntijalle ja lisäksi 5 haastateltiin (vastaus-\% 55,5).

Kyselyyn vastanneiden asiantuntijoiden taustatiedot on poimittu asiantuntijoiden ensimmäisen Delfoi-kierroksen internetkyselyn ja henkilöhaastatteluiden vastauksista. Kuviossa 1 on esitetty asiantuntijoiden työskentelytausta. Molemmilla kyselykierroksilla asiantuntijoiden toimialajakauma oli pääosin sama. Poikkeuksena kierrosten välillä oli kaupan ja panosteollisuuden asiantuntijoiden puuttuminen toiselta kierrokselta. Suurin osa asiantuntijoista työskenteli tutkimuksessa, hallinnossa, alkutuotannossa ja edunvalvonnassa.

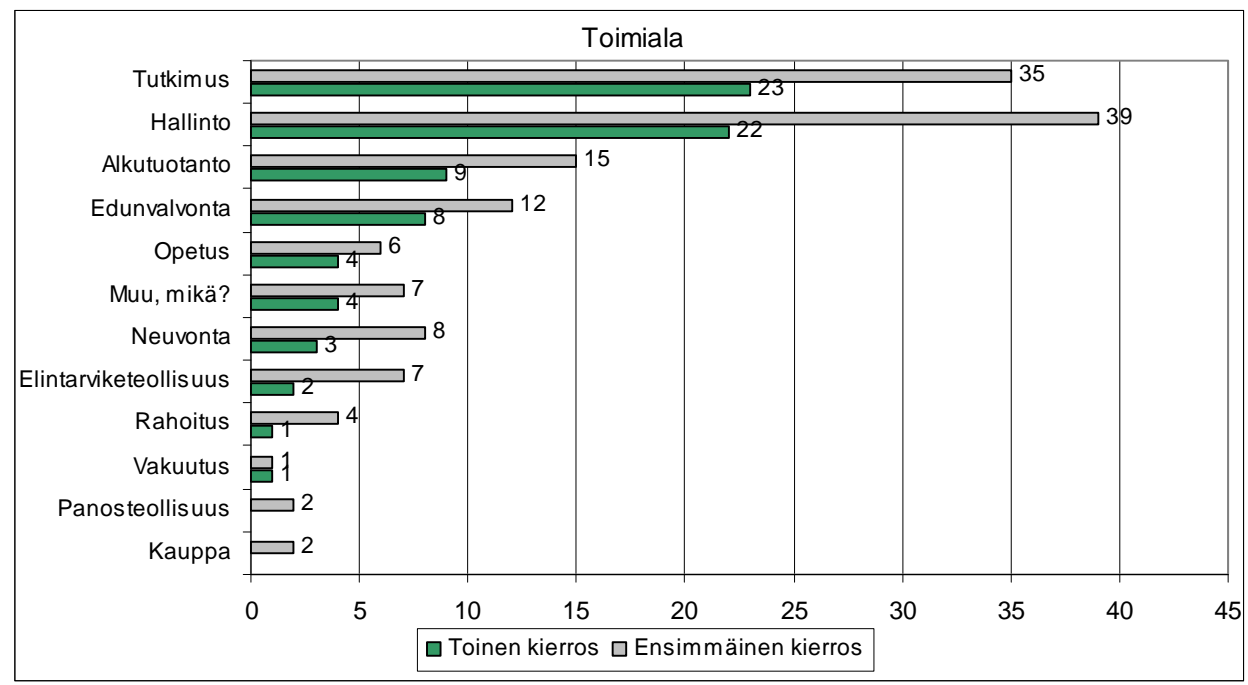

Kuvio 1. Asiantuntijoiden toimialat.

Asiantuntijavalinnalla ei haettu tässä tutkimuksessa tilastollisesti edustavien ryhmien valintaa vaan sitä, että asiantuntijat täydentäisivät asiantuntemuksellaan mahdollisimman hyvin toisiaan. Asiantuntijavalinnan apuna ja kriteerinä käytettiin kahta matriisia, joissa kotimaista elintarvikeketjua tarkasteltiin sekä tutkimuksen neljän tutkimusteeman että asiantuntija- ja toimikenttäulottuvuuksien mukaan mahdollisimman kattavan asiantuntijuuspeiton saamiseksi mukaan tutkimukseen. 
Taulukko 1. Maa- ja elintarviketalouteen liittyvät työtehtävät.

\begin{tabular}{lcccc}
\hline Osallistuminen & Frekvenssi, 1. kierros (\%) & \multicolumn{2}{l}{ Frekvenssi, 2. kierros (\%) } & $(77,0)$ \\
\hline Päivittäin & 88 & $(80,0)$ & 47 & $(11,5)$ \\
Viikoittain & 12 & $(10,9)$ & 7 & $(6,6)$ \\
Kuukausittain & 6 & $(5,5)$ & 4 & $(3,3)$ \\
Vuosittain & 2 & $(1,8)$ & 2 & $(0)$ \\
Harvemmin & 0 & $(0)$ & 0 & $(1,6)$ \\
Tyhjä vastaus & 2 & $(1,8)$ & 1 & $(100)$ \\
\hline Yhteensä & 110 & $(100)$ & 61 & \\
\hline
\end{tabular}

Taulukossa 1 on esitetty, kuinka usein asiantuntijoiden työtehtävät liittyvät maa- ja elintarviketalouteen. Aktiivisuudesta päätellen ei kierrosten välillä ollut juurikaan muutosta. Suurin osa asiantuntijoista oli tekemisissä maa- ja elintarviketalouteen koskevien asioiden kanssa päivittäin molemmilla kyselykierroksilla. Toisen kierroksen kyselyyn vastanneista päivittäin maa- ja elintarviketaloudessa työskentelevien osuus hieman laski.

Taulukko 2. Asiantuntijoiden asuinpaikat

\begin{tabular}{lcccc}
\hline Asuinpaikka & \multicolumn{2}{c}{ Frekvenssi, 1. kierros (\%) } & \multicolumn{2}{c}{ Frekvenssi, 2. kierros (\%) } \\
\hline Pääkaupunkiseutu & 45 & $(40,9)$ & 28 & $(45,9)$ \\
Kaupunki tai kaupunkimainen maaseutu & 36 & $(32,7)$ & 20 & $(32,8)$ \\
Maaseudulla & 28 & $(25,5)$ & 13 & $(21,3)$ \\
Tyhjä vastaus & 0 & $(0)$ & 0 & $(0)$ \\
\hline Yhteensä & 110 & $(100)$ & 61 & $(100)$ \\
\hline
\end{tabular}

Taulukossa 2 on esitetty asiantuntijoiden taustat asuinpaikan mukaan. Vastausten perusteella asiantuntijoista lähes puolet asui pääkaupunkiseudulla. Selvästi yli puolet asiantuntijoista asui joko Uudenmaan tai Itä-Uudenmaan maakunnassa. Delfoi-kierroksen asiantuntijoiden asuinpaikkoja voidaan vastauksista tulkita etenkin maaseudulla asuvien asiantuntijoiden jättäneen vastaamatta toisen kierroksen kyselyyn. Ensimmäisellä kyselykierroksella vastanneiden asiantuntijoiden työhistoria oli keskimäärin 20,5 vuotta ja toisella 19,8 vuotta.

Muutostekijät luokiteltiin eri politiikkahaasteryhmiin, jossa apuna käytettiin kuvion 2 mukaista ryhmittelyä. ”Merkitys tulevaisuuden kehitykseen” -ulottuvuudessa määrittävänä kriteerinä käytettiin asiantuntijoiden muutostekijöistä antamien tärkeysarviointien keskiarvoa. Muutostekijän, joka sai kaikkien muutostekijöiden tärkeysarviointien keskiarvoa pienemmän arvon, merkitys tulevaisuuden kehitykseen tulkittiin pieneksi. Keskiarvoa suuremman arvon saanut muutostekijän merkitys tulevaisuuden kehitykseen tulkittiin suureksi. Määrittävänä kriteerinä "politiikkaristiriidan todennäköisyys" ulottuvuustarkastelussa käytettiin asiantuntijoiden vastauksia muutostekijöiden toivotusta ja todennäköisestä muutoksesta. Politiikkaristiriidan todennäköisyys on suuri muutostekijällä, jonka toivottu ja todennäköinen muutos on erisuuntainen. Vastaavasti samansuuntaisilla politiikkaristiriidan todennäköisyys on pieni. Tutkimuksen kannalta keskeisimpiä muutostekijöitä ovat ne, joilla on suuri merkitys tulevaisuuden kehitykseen, ja joilla politiikkaristiriitojen todennäköisyys on suuri. 


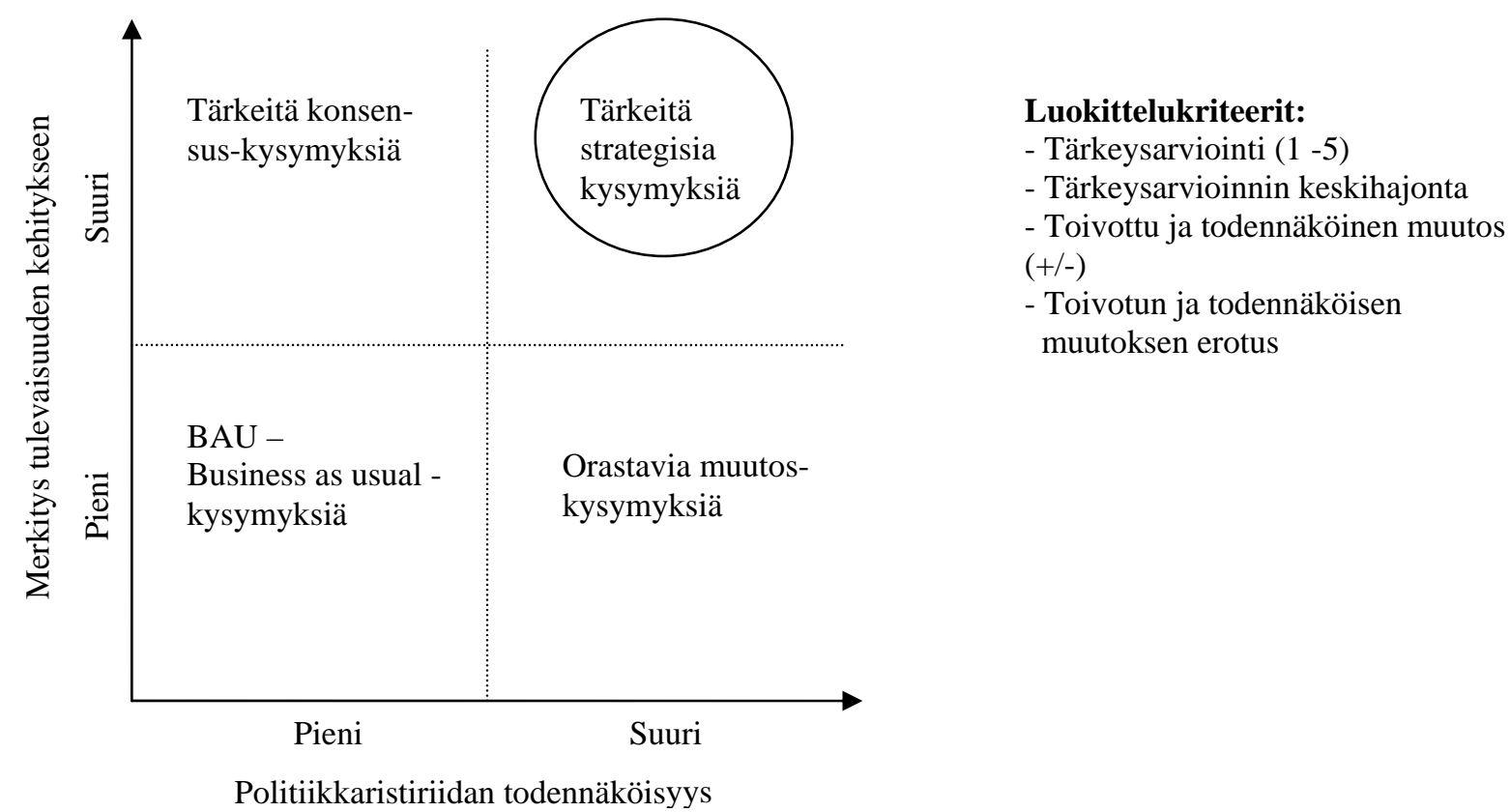

Kuvio 2. Politiikkahaasteiden tunnistaminen (Rikkonen ym. 2006, Aakkula ym. 2008).

\section{Tulokset}

Muutostekijöiden 5-portaisella Likert -asteikolla kysytyistä ulottuvuuksista (tärkeydestä, toivottavasta ja todennäköisestä tulevaisuudenkuvasta) laskettiin keskiarvot ja keskihajonnat. Ensimmäisellä Delfoikierroksella kysyttyjen 86 muutostekijän luokittelu on esitelty taulukossa 3. Tummennetulla värillä on esitetty tärkeiden strategisten kysymysten luokittuminen. Yhteensä tähän ryhmään luokittui 20 kysytyistä muutostekijöistä, muutoksista tai trendeistä.

Taulukko 3. Muutostekijöiden luokittelukriteerit (Aakkula, Rikkonen ja Rajaniemi 2008).

\begin{tabular}{|c|c|c|c|c|}
\hline $\begin{array}{l}\text { Tärkeysarvioinnin } \\
\text { keskiarvo A }\end{array}$ & $\begin{array}{l}\text { Tärkeysarvioinnin } \\
\text { keskihajonta }^{\mathrm{B}}\end{array}$ & $\begin{array}{l}\text { Toivottu ja to- } \\
\text { dennäköinen } \\
\text { muutos }^{C}\end{array}$ & $\begin{array}{l}\text { Toivotun ja todennä- } \\
\text { köisen muutoksen } \\
\text { erotus }{ }^{D}\end{array}$ & $\begin{array}{l}\text { Kysyttyjen } 86 \\
\text { muutostekijän luokit- } \\
\text { tuminen }\end{array}$ \\
\hline \multirow{8}{*}{ pieni } & \multirow{4}{*}{ pieni } & & pieni & 4 \\
\hline & & erisuuntainen & suuri & 0 \\
\hline & & \multirow{2}{*}{ samansuuntainen } & pieni & 5 \\
\hline & & & suuri & 1 \\
\hline & \multirow{4}{*}{ suuri } & \multirow{2}{*}{ erisuuntainen } & pieni & 8 \\
\hline & & & suuri & 1 \\
\hline & & \multirow{2}{*}{ samansuuntainen } & pieni & 12 \\
\hline & & & suuri & 10 \\
\hline \multirow{8}{*}{ suuri } & \multirow{4}{*}{ pieni } & \multirow{2}{*}{ erisuuntainen } & pieni & 5 \\
\hline & & & suuri & 12 \\
\hline & & \multirow{2}{*}{ samansuuntainen } & pieni & 6 \\
\hline & & & suuri & 12 \\
\hline & \multirow{4}{*}{ suuri } & \multirow{2}{*}{ erisuuntainen } & pieni & 0 \\
\hline & & & suuri & 3 \\
\hline & & \multirow{2}{*}{ samansuuntainen } & pieni & 4 \\
\hline & & & suuri & 5 \\
\hline
\end{tabular}

\footnotetext{
${ }^{A}$ Muutostekijöiden tärkeysarvioinnin keskiarvo. Muutostekijän tärkeysarviointi on suuri jos se on suurempi kuin kaikkien muutostekijöiden tärkeysarvioinnin keskiarvo.

${ }^{\mathrm{B}}$ Muutostekijöiden tärkeysarviointien keskihajontojen keskiarvo. Muutostekijän keskihajonta on suuri jos se on suurempi kuin kaikkien keskihajontojen keskiarvo.

${ }^{\mathrm{C}}$ Toivotun ja todennäköisen muutoksen samansuuntaisuus. Toivottu ja todennäköinen muutos ovat samansuuntaisia, jos toivottu ja todennäköinen arvioitu muutos on molempien muutosten osalta esimerkiksi positiivinen.

D Toivotun ja todennäköisen muutoksen absoluuttisten arvojen erotuksen keskiarvo. Muutostekijän toivotun ja todennäköisen erotus on suuri silloin kun se on suurempi kuin kaikkien muutostekijöiden toivottujen ja todennäköisten muutosten keskiarvo.
} 
Tärkeysarvioinnissa, mitä korkeampi keskiarvo on, sitä tärkeämpi muutostekijä on kotimaiselle elintarvikeketjulle asiantuntijoiden näkemyksen mukaan. Muutostekijän tärkeysarvioinnin keskihajonta kuvaa kuinka paljon asiantuntijoiden näkemykset muutostekijän tärkeydestä eroavat keskenään. Mitä pienempi keskihajonta on, sitä vähemmän asiantuntijoiden keskinäiset näkemykset eroavat toisistaan. Asiantuntijoiden arvioimia toivottua ja todennäköistä muutosta käytettiin politiikkaristiriitojen todennäköisyyden selvittämisessä. Muutostekijöiden erimerkkisyys kuvastaa sitä, että nykypolitiikalla ei päästä tavoitetilaan. Erotus taas sitä, kuinka kaukana toivottu ja todennäköinen tulevaisuudenkuva on toisistaan. Mitä suurempi erotus sitä epätodennäköisemmin nykypolitiikalla voidaan vaikuttaa. Tärkeyden perusteella listatut strategiset muutostekijät, muutokset ja trendit on esitetty taulukossa 4.

Taulukko 4. Tärkeät strategiset muutostekijät

\begin{tabular}{|c|c|c|c|c|c|c|}
\hline 1. Makean veden varannot maailmassa & 4,80 & 0,45 & 1,08 & $-1,09$ & 2,25 & 3,94 \\
\hline $\begin{array}{l}\text { 2. Euroopan unionin vaikutus Suomen kansalliseen maatalous- ja } \\
\text { maaseutupolitiikkaan }\end{array}$ & 4,65 & 0,60 & $-0,71$ & 0,51 & 1,36 & 3,74 \\
\hline 3. EU:n rahoittaman maataloustuen määrä Suomessa & 4,57 & 0,65 & 0,56 & $-0,91$ & 1,55 & 3,73 \\
\hline 4. EU:n maatalousbudjetti rahoituskaudella $2014-2020$ & 4,57 & 0,63 & 0,20 & $-0,75$ & 1,25 & 3,77 \\
\hline 5. Alkutuotannon panoshinnat Suomessa & 4,56 & 0,59 & $-0,81$ & 0,72 & 1,73 & 3,49 \\
\hline $\begin{array}{l}\text { 6. Kotimaisten elintarvikkeiden osuus elintarvikkeiden kokonais- } \\
\text { kulutuksesta Suomessa }\end{array}$ & 4,49 & 0,66 & 1,14 & $-0,47$ & 1,61 & 3,61 \\
\hline 7. Maaperän eroosio maailmanlaajuisesti & 4,44 & 0,68 & $-1,36$ & 0,90 & 2,35 & 3,88 \\
\hline $\begin{array}{l}\text { 8. Kansallisten tukien osuus maatalouden kokonaistukimäärästä } \\
\text { Suomessa }\end{array}$ & 4,35 & 0,74 & 0,37 & $-0,02$ & 1,07 & 3,50 \\
\hline 9. Sään ääri-ilmiöt (esim. kuivuus, tulvat) Suomessa & 4,35 & 0,74 & $-1,00$ & 1,16 & 2,21 & 3,86 \\
\hline 10. EU:n maatalousbudjetti rahoituskaudella 2021 - 2027 & 4,31 & 0,76 & 0,16 & $-0,83$ & 1,22 & 3,55 \\
\hline 11. Maidon tuotantomäärä Suomessa & 4,25 & 0,71 & 0,38 & $-0,47$ & 0,96 & 3,65 \\
\hline $\begin{array}{l}\text { 12. Liikkumavara kansallisesti rahoitetun maataloustuen määrässä } \\
\text { Suomessa }\end{array}$ & 4,24 & 0,70 & 0,94 & $-0,36$ & 1,41 & 3,59 \\
\hline 13. Tuotantoeläinten eläintaudit Suomessa & 4,23 & 0,85 & $-0,91$ & 0,51 & 1,51 & 3,58 \\
\hline 14. Lihan osuus ruokavaliosta maailmassa & 4,20 & 0,79 & $-0,24$ & 0,57 & 1,08 & 3,68 \\
\hline 15. EU:n maatalouspolitiikan epävarmuus & 4,19 & 0,84 & $-1,16$ & 0,48 & 1,77 & 3,55 \\
\hline 16. Viljelijätukien irrottaminen tuotannosta EU:ssa & 4,18 & 0,88 & $-0,23$ & 0,50 & 1,49 & 3,99 \\
\hline 17. Investointitukien määrärahat Suomessa & 4,12 & 0,77 & 0,56 & $-0,42$ & 1,12 & 3,47 \\
\hline $\begin{array}{l}\text { 18. Rikkakasvi-, kasvitauti- ja tuholaisongelmat maataloudessa } \\
\text { Suomessa }\end{array}$ & 4,08 & 0,85 & $-1,06$ & 0,99 & 2,10 & 3,82 \\
\hline $\begin{array}{l}\text { 19. Poliittinen liikkumavara kansallisten maataloustukien sisällön } \\
\text { osalta Suomessa }\end{array}$ & 4,08 & 0,89 & 0,96 & $-0,29$ & 1,38 & 3,42 \\
\hline $\begin{array}{l}\text { 20. Ulkomaisen raaka-aineen (liha, maito, vilja) käytön määrä } \\
\text { elintarviketeollisuudessa Suomessa }\end{array}$ & 4,05 & 0,90 & $-0,77$ & 0,74 & 1,50 & 3 \\
\hline
\end{tabular}

Ensimmäisen kierroksen tuloksena "tärkeät strategiset muutostekijät” ryhmään luokittui yhteensä 20 kysytyistä muutostekijöistä, muutoksista tai trendeistä. Tulosten mukaan neljästä kysytystä (1. instituutiot ja politiikka, 2. alkutuotanto ja yrittäjätoiminta, 3. elintarvikkeet ja markkinat, 4. energia ja ympäristö) teema-alueesta voidaan jäsennellä selkeästi tärkeimmäksi teema-alueeksi instituutioiden ja politiikan muutokset. Teemaan luokittui 10 muutostekijää kysytystä 20:stä. 
Tärkeimpinä nähtiin EU:n vaikutus Suomen kansalliseen maatalous- ja maaseutupolitiikkaan, asiantuntijat toivoivat EU:n vaikutuksen vähenemistä, mutta pitivät todennäköisenä sen kohtalaista lisääntymistä. Todennäköistä muutosta pidettiin myös kohtalaisen varmana. Toisena kysymyksenä EU:n rahoittaman maataloustuen määrän Suomessa toivottiin jonkin verran lisääntyvän, mutta todennäköisenä pidettiin EU-tuen selkeää laskua. EU:n maatalousbudjetin toivottiin rahoituskaudella 2014 2020 hienoisesti nousevan $(+0.20$, asteikolla $-2 \ldots+2)$, mutta todennäköisesti selkeästi laskevan $(-0,75)$. Kansallisten tukien osuuden nähtiin pysyvän ennallaan, eikä liikkumavarankaan suuremmin nähty kansallisesti kasvavan. Maatalouspolitiikan epävarmuuden osalta toivottavan ja todennäköisen tulevaisuuden välinen ero oli suurin, joten kysyntä toimille, joilla epävarmuutta saadaan pienennettyä, on selkeä.

Energia ja ympäristö -teemassa toivottavan ja todennäköisen tulevaisuuden erot olivat suurimpia (erot 2.10-2.35 välillä, asteikolla -2 ..+2), ja tärkeät strategiset muutostekijät -ryhmään luokittui 4 muutostekijää. Kysymysten osalta ollaan siis selkeästi eri tulevaisuuspolulla kuin olisi asiantuntijoiden mukaan toivottavaa. Myös todennäköisen tulevaisuuden osalta nähtiin muutosten olevan negatiivisesti maa- ja elintarviketalouteen vaikuttavia. Makean veden varantoon, maaperän eroosioon, sään ääriilmiöihin ja rikkakasvi-, kasvitauti- ja tuholaisongelmiin liittyvät kysymykset nähtiin siis keskeisinä tulevaisuuskysymyksinä, joissa vaikutus tulevaisuuden kehitykseen on suuri, ja joihin lisäksi sisältyy myös suuri politiikkaristiriita.

Loput muutostekijöistä luokittuivat "alkutuotanto ja yrittäjätoiminta” sekä "elintarvikkeet ja markkinat" -teemoihin. Alkutuotannon panoshintojen toivottiin selkeästi alenevan, todennäköisenä kuitenkin pidettiin pitkällä aikavälillä niiden nousua. Todennäköisen tulevaisuuskuvan toteutumisen varmuus kehityksestä jäi ryhmässä suhteellisen alhaiselle tasolle. Kotimaisten elintarvikkeiden osuuden elintarvikkeiden kokonaiskulutuksesta toivottiin kasvavan, tosin todennäköisenä pidettiin osuuden edelleen alenevan nykyisestä noin 30 \%:sta. Suomen maataloudessa tärkeimmän tuotantosuunnan, maidontuotannon nähtiin jonkin verran alenevan, toive tuotantovolyymin kasvattamisestakaan ei ollut suuri. Tuotantoeläinten eläintautien nähtiin jonkin verran lisääntyvän, toive eläintautien alenemisesta oli kuitenkin selkeä. Lihan osuuden ruokavaliosta maailmassa toivottiin hienoisesti vähenevän, todennäköisenä pidettiin kuitenkin osuuden nousua. Ulkomaisen raaka-aineen (liha, maito, vilja) käytön määrän elintarviketeollisuudessa nähtiin Suomessa kasvavan selkeästi.

Toisella Delfoi -kierroksella haluttiin tiivistää ja vetää yhteen ensimmäisen kierroksen aineistosta esille nousevat kysymykset. Toisella kyselykierroksella keskityttiin muutostekijöihin, joilla on keskeinen rooli kotimaisen elintarvikeketjun näkökulmasta. Asiantuntijoiden tärkeimmiksi arvioimat muutostekijät olivat 1) maatilojen kannattavuus Suomessa, 2) EU:n vaikutus Suomen kansalliseen maatalous- ja maaseutupolitiikkaan, 3) kotimaisten elintarvikkeiden osuus kokonaiskulutuksesta Suomessa, 4) EU:n maatalousbudjetti rahoituskaudella 2014 - 2020 ja 5) Maatalouden vesistöihin tuottama fosforikuormitus Suomessa. Asiantuntijoiden perustelivat maatilojen kannattavuuden merkitystä sen roolilla koko elintarvikeketjun näkökulmasta. Asiantuntijat toivoivatkin maatilojen kannattavuuden parantuvan nykytasolta merkittävästi. Toivotun muutoksen suuntaan ja määrään vaikutti osaltaan tieto maatilojen kannattavuuden nykytilasta. Rakennekehitys ja maatilayrittäjien ammattitaidon lisääntyminen voivat osaltaan vaikuttaa positiivisesti maatilojen kannattavuuteen. Asiantuntijat kuitenkin pitivät todennäköisenä, että maatilojen kannattavuus ei nykytilanteesta tule merkittävästi paranemaan. Rakennekehitys ei yksistään paranna kannattavuutta, lähinnä sillä ylläpidetään nykyinen taso. Asiantuntijat painottivat enemmänkin ammattitaitoa. Maatilojen kannattavuus voi parantua myös uusien tuotantojärjestelmien myötä, joita joudutaan kehittelemään mahdollisten ruoan ja panosten hintapiikkien seurauksena. Alkutuotannossa maidontuotanto suurimpana yksittäisenä tuotantoalana on tärkeä nyt ja tulevaisuudessa. Toimintaympäristön muuttuessa haasteena on vastata tiukentuvaan ulkomaiseen kilpailuun.

Asiantuntijoiden mielestä EU:n vaikutus Suomen kansalliseen maatalous- ja maaseutupolitiikkaan tulisi vähentyä nykytasosta. Asiantuntijat perustelivat toivettaan sillä, että kansallisella maatalouspolitiikalla voitaisiin paremmin ottaa huomioon kansallisia tavoitteita, kuten maatilojen kannattavuuden parantaminen. EU:lla on jo nykyisellään varsin suuri rooli. Tilanne voi muuttua tulevien maatalouspoliittisten uudistusten myötä, mutta nykyisten maatalouspoliittistenlinjausten perusteella EU:n vaikutus tulisi säilymään myös jatkossa. Yhtenä mahdollisena epävarmuustekijänä asiantuntijat näkivät nykyiset taloudelliset resurssit. 
Asiantuntijat toivoivat, että kotimaisten elintarvikkeiden osuus kokonaiskulutuksesta lisääntyisi nykytasosta vuoteen 2030 mennessä. Asiantuntijoiden mielestä osuus olisi jo nykyisellään laskenut huomattavan alhaiselle tasolle. Asiantuntijat perustelivat osuuden lisäystä muun muassa alkutuotannon kannattavuuden näkökulmalla ja kotimaisen elintarviketeollisuuden elinvoimaisuudella. Todennäköisesti kotimaisen ruuan osuus tulee kuitenkin pienenemään hieman nykytasosta vuoteen 2030 mennessä, koska kuluttajat ovat yhä enemmän kokeilunhaluisia ja hintatietoisempia. Osuuden pienenemistä asiantuntijat pitivät todennäköisenä ja taustalla vaikuttaa yhä useammin myös kauppojen omat merkit, joiden osuus kokonaistuotevalikoimasta on kasvanut nopeasti. Omien merkkien tuotanto on paikasta riippumatonta. Tilanteessa voi tapahtua äkkinäisiäkin muutoksia esimerkiksi ruokakriisien seurauksena. Ruokakriisit voivat olla sekä ulkoapäin tulevia että sisäisesti tapahtuvia. Yksistään puhtauteen ja ruokaturvallisuuteen perustuva kotimaisuuden markkinointi voi aiheuttaa tulevaisuudessa myös ongelmia, jos kotimaisen elintarviketuotannon perusta kriisien kautta järkkyy.

\section{Yhteenveto}

Tutkimuksessa tarkasteltiin elintarvikeketjun asiantuntijoiden tulevaisuudenkuvia määriteltyjen teemojen alla. Tutkimuksen empiirinen osuus kohdistui elintarvikeketjun asiantuntijoihin, eli juuri niihin toimijoihin, jotka myös yhteisiä strategioita ja painopisteitä tulevaisuuden maa- ja elintarviketalouden osalta suunnittelevat ja toteuttavat.

Toisella Delfoi-kierroksella asiantuntijoiden painottamat, tarkennetut huolenaiheet, luokiteltiin Suomen maa- ja elintarviketalouden strategisesti tärkeiksi kysymyksiksi. Niissä korostuivat viisi toimialalle keskeistä asiaa: maatilayritysten kannattavuuden kehitys, Euroopan unionin yhteisen maatalouspolitiikan painoarvo Euroopan unionin toiminnassa ja kansallisen liikkumavaran käyttömahdollisuudet yhteiskunnallisesti hyväksyttävin perusteluin, EU:n maatalousbudjetin rahamääräinen toteuma rahoituskaudelle 2014 - 2020, kotimaisten elintarvikkeiden osuuden väheneminen ruoankulutuksessa tuontielintarvikkeiden lisääntyessä sekä maatalouden ympäristökuormituksen hallinta erityisesti fosforikuormituksen osalta. Asiantuntijat kokivat voivansa vaikuttaa vähiten muutostekijöissä, jotka liittyivät maailmanlaajuisiin ympäristökysymyksiin kuten ilmastonmuutoksen vaikutuksiin. Vaikutusmahdollisuutena asiantuntijat näkivät kuitenkin lainsäädännön ja erilaiset tukitoimet.

Asiantuntijoiden vastausten epävarmuus kasvoi, mitä pidemmälle tulevaisuuteen muutostekijän kehitystä ennakoitiin. Perusteluissaan he totesivat edessä olevan paljon sekä maatalouspolitiikkaan että ilmastoon liittyviä muutoksia, joiden ajankohdasta tai toteutumisesta tai sen asteesta ei vielä ole varmuutta. Haastateltavat kommentoivatkin, että tulevaisuusnäkemysten antaminen on selkeämpää esimerkiksi seuraavien 5 vuoden päähän. Ennakoinnin aikaperspektiivin pituuden tuomasta vaikeudesta on tulevaisuudentutkimuksessa keskusteltu paljon. Tämä korostaakin skenaariosuunnittelun tärkeyttä osana Delfoi-menetelmän käyttöä. Skenaariosuunnittelussa luodaan vaihtoehtoisia, loogisesti eteneviä nykyhetkestä lähteviä tapahtumasarjoja, joiden tarkoituksena on näyttää, miten mahdollinen, joko todennäköinen, tavoiteltava tai uhkaava tulevaisuudentila kehittyy askel askeleelta joko nykytilasta tulevaisuuteen tai tulevaisuuden tavoitetilasta nykyhetkeen.

\section{Kirjallisuus}

Armstrong, J.S. 2001. Principles of forecasting. A handbook for researchers and practitioners. Boston/Dordrecht/London: Kluwer Academic Publishers.

Bell, W. 1997. Foundations of Future Studies - Human science for a new era. Volume I and II. Transaction Publishers, New Brunswick, New Jersey. 365 s.

Kuusi, O. 2003. Delfoi-menetelmä. In: Vapaavuori, M \& Von Bruun, S. (ed.) Miten tutkimme tulevaisuutta. Second Edition. Tampere: Tammer-Paino Ltd. pp. 134-144.

Rikkonen, P., Aakkula, J. \& Kaivo-oja, J. 2006. How can future changes in Finnish agriculture and agricultural policy be faced : defining strategic agenda on the basis of a Delphi study. European planning studies 14, 2: 147-168.

Rikkonen, P., Aakkula, J. \& Rajaniemi, M. 2008. The future of milk in the light of the agricultural policy changes towards 2025 - a delphi study on future challenges of the Finnish milk sector. In: The 109th EAAE Seminar "The CAP after the Fischler reform: National implementations, impact assessment and the agenda for future reforms". $15 \mathrm{p}$. 